\title{
Growth and yield of wheat at different dates of sowing under chrland ecosystem of Bangladesh
}

\author{
M. M. Kamrozzaman ${ }^{1}$, M. A. H. Khan ${ }^{2 *}$, S. Ahmed ${ }^{3}$ and N. Sultana ${ }^{2}$ \\ ${ }^{1}$ Spices Research Centre, Faridpur; ${ }^{2}$ On-Farm Research Division, Mymensingh and ${ }^{3}$ On-Farm Research Division, \\ Faridpur, Bangladesh, E-mail: helim1367@gmail.com
}

\begin{abstract}
An experiment was conducted at Sadipur charland under Farming System Research and Development Site, Hatgobindapur, Faridpur, during rabi season of 2012-13 and 2013-14 to study the growth and yield performance of cv. BARI Gom-24 as affected by different dates of sowing under Agro-ecological Zone-12 (AEZ-12) of Bangladesh. The experiment was laid out in randomized complete block design with six replications, comprising five different dates of sowing viz. November 5, November 15, November 25, December 5 and December 15. Results reveal that the tallest plant, leaf area index, total dry matter, and crop growth rate were observed in November 25 sown crop and leaf area index, total dry matter and crop growth rate were higher at booting, grain filling, and tillering stages of the crop. Maximum effective tillers hill ${ }^{-1}$ (3.49), spikes $\mathrm{m}^{-2},(311)$, number of grains spike ${ }^{-1}(42.20)$ and 1000 -grain weight (52.10 g) were produced by November 25 sown crop exhibited the highest grain $\left(4.30 \mathrm{t} \mathrm{ha}^{-1}\right)$ and straw yield $\left(4.94 \mathrm{t} \mathrm{ha}{ }^{-1}\right)$ as well as harvest index (46.88\%) of the crop. Lowest performance was observed both in early (November 5) and late sown crop (December 15). The overall results indicated that November 25 sown crop showed better performance in respect of growth and yield of wheat under charland ecosystem of Bangladesh.
\end{abstract}

Keywords: Charland, Ecosystem, Date of sowing, Wheat, Growth, Yield

\section{Introduction}

Wheat (Triticum aestivum L.) is the world's most outstanding crop that excels all other cereals both in area and production known as king of cereals (Costa et al., 2013). It is also one of the most nutritious cereals that contributed to human diet puts it in the first rank to feed the world. In Bangladesh, it is the second major cereal crop after rice. It occupies near about $0.36 \mathrm{~m}$ ha of land and making up $6 \%$ of the cereal production to about $1.0 \mathrm{~m}$ ton with an average yield of 2.78 tha $^{-1}(\mathrm{BBS}, 2012)$ and thus contributing greatly to the national cereal production of Bangladesh. Consumption rate of wheat is increasing day by day due to its moderate production cost, good market value and nutrition level. In Bangladesh, with changing of food habit, wheat has become one of the essential grain crop and its production represents a special position in agricultural policies. But the average productivity of wheat is comparatively low than that of rice and maize due to many biotic and abiotic factors. Among various factors responsible for low yield of wheat crop in the country, sowing date and varietal selection are of primary importance. Optimum time for sowing wheat in Bangladesh is between mid November to $1^{\text {st }}$ week of December. About $85 \%$ of the total wheat area follows previous rice crop and over $60 \%$ of the total wheat is cultivated at late sowing condition (Badruddin et al. 1994). Too early sowing produces weak plants with poor root system as the temperature is above optimum which leads to irregular germination, frequent death of embryo and decomposition of endosperm due to activities of bacteria or fungi. Tahir et al. (2009) reported that delay sowing affects germination, growth, grain development and produces poor tillering due to winter injury in low temperature and suppressed the yield. Normal sowing prolongs the duration of tillering and produces more number of tillers, number of spikes, grains spike ${ }^{-1}$ and grain weight that ultimately boosts up grain and straw yields (Qasim et al., 2008). Singh and Uttam (1999) estimated yield loss @ $39 \mathrm{~kg} / \mathrm{ha} /$ day for each day delay in sowing from optimum sowing date. It was reported that about $1.3 \%$ reduction in grain yield occurs for each day delay after the first day of December. Wiegard and Cellular (1981) also reported that increase of each $1.0^{\circ} \mathrm{C}$ in mean daily air temperature during grain filling of wheat resulted in decrease of 3 days in grain filling period.

It is reported that Bangladesh has about 0.82 million ha of non saline char which is about $5 \%$ of total area and about 6.5 million people which is $5 \%$ of total population live on the chars. Ahmed et al. (1987) estimated that 64 to $97 \%$ areas are cultivable of total charland of Bangladesh. In Faridpur district, the total char land area (including Sadar, Char Vadrason and Sadarpur upazilla of Faridpur) is 19780 hectare 
out of which $75 \%$ is cultivable land (DAE, 2010). The char area is categorized based on recession of flood water viz. high charland, medium high char land and low charland which is $44 \%, 32 \%$ and $24 \%$, respectively with triple, double and single crops are cultivating there regularly. In char area, dearth of water tends the people to cultivate less water requirement type of crops like wheat, blackgram, mungbean etc. Yield of wheat is low (2 to $2.5 \mathrm{t} / \mathrm{ha}$ ) in char land compared to other places of Bangladesh due to many biotic and abiotic factors (Kamruzzaman, 2013). These factors limit wheat productivity because every crop cultivar has its own requirements for particular environmental conditions for maximum growth which could be facilitated by proper sowing date. It is very essential to increase per hectare yield of wheat. However, some research on different sowing date performance is also obtained in various regions of the world with some scientist to find out the most suitable sowing time. Wheat Research Center of BARI has developed a good number of high yielding and stress tolerant wheat varieties which are less susceptible to pest and disease. Wheat crop becomes popular in Faridpur region (Agro-ecological zone 12) after harvesting of T.Aman rice. So there is a scope of disseminating the new wheat varieties among the farmers in the char land areas. Keeping this in view, the study was designed to determine the effects of different sowing dates on growth, yield and yield components of wheat under charland ecosystem of Faridpur.

\section{Materials and Methods}

The experiment was conducted at Sadipur charland of FSRD site, Hatgobindapur, Bangladesh Agricultural Research Institute (BARI), Faridpur during rabi season of 2012-13 and 2013-14. It belongs to the Low Ganges River Floodplain Agro-ecological Zone (AEZ-12). The geographical position of the area is between $23^{\circ} 33^{\prime} \mathrm{N}$ latitude and $89^{\circ} 44^{\prime} \mathrm{E}$ longitude. The soils are mostly sandy to silt loam in texture and almost neutral in reaction having $\mathrm{pH}$ range of 6.8 to 7.1. The organic matter content of the soil was about $1.22 \%$. Nitrogen was very low $(0.074 \%)$ but phosphorus $\left(15.25 \mathrm{mg} \mathrm{g}^{-1} \mathrm{soil}\right)$ and boron $\left(0.32 \mathrm{mg} \mathrm{g}^{-1}\right.$ soil) level were close to critical limit. Potassium (0.24 meq100 $\left.\mathrm{g}^{-1} \mathrm{soil}\right)$, sulpher (17.10 $\mathrm{mg} \mathrm{g}^{-1}$ soil) and zinc (1.12 $\mathrm{mg} \mathrm{g}^{-1}$ soil) content were medium in the soil.

The meteorological data of the experimental site revealed that the highest temperature $\left(33.81^{\circ} \mathrm{C}\right)$ in March and the lowest in January $\left(11.84^{\circ} \mathrm{C}\right)$. The relative humidity was the highest $(82.61 \%)$ in December and the lowest $(64.75 \%)$ in February. The crop received $(90.07 \mathrm{~mm})$ rain showers from November to March. The experiment was laid out in a randomized complete block design with six replications comprising five dates of sowing viz. November 5, November 15, November 25, December 5 and December 15, used BARI Gom-24 as test crop. Unit plot size was $5 \mathrm{~m} \times 4 \mathrm{~m}$. The crop received fertilizer dose of $115-35-56-5-2-1 \mathrm{~kg} \mathrm{ha}^{-1}$ of NPKSZnB in the form of urea, triple super phosphate, muriate of potash, gypsum, zinc sulphate and boric acid, respectively. Two thirds of urea and entire amount of all other fertilizers were applied at the time of final land preparation. Rest of urea was applied in two equal splits one at 21 days and another at 48 days after sowing followed by irrigation. Before sowing, seeds were treated with provex-200 WP and sown @120 kg ha ${ }^{-1}$ in lines maintaining $20 \mathrm{~cm}$ apart. Intercultural operations such as weeding and irrigation were done as per the need of the crop.

Destructive plant samples at each growth stage were collected from each plot for collecting data on growth parameters and it started from crown root initiation stage (CRI) and continued up to grain filling stage. Five plants per plot were carefully uprooted randomly at each growth stage. Different plant parts (total dry matter, leaf area index and crop growth rate) were calculated by classical techniques of growth analysis following the standard methods (Gardner et al., 1985 and Hunt, 1978). At maturity, ten plants from each treatment were harvested and yield components were recorded. The crop was harvested plot

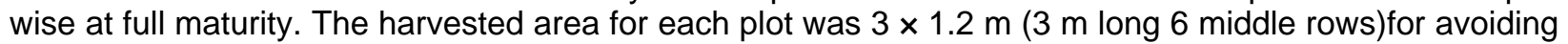
border effect. The seed and straw weight for each plot were recorded after sun drying to constant weight. The grain and straw yield was finally converted into $\mathrm{t} \mathrm{ha}^{-1}$. The harvest index (\%) was calculated according to the following formula.

Harest Index $(\mathrm{HI})=\frac{\text { Grain yield }}{\text { Biological yield }} \times 100$ 
The data were analyzed statistically with computer package programme MSTAT-C. Mean comparison among the treatments were made by Duncan's Multiple Range Test (DMRT) at 5\% level of probability (Gomez and Gomez, 1984) and pooled analysis was done as because there was no significant variation in growth, yield and yield parameters between the years.

\section{Results and Discussion}

\section{Total dry matter (TDM)}

The highest total dry matter (TDM) production was obtained in November 25 sowing compared to other sowing dates (Fig. 1). The crop sown on this date may have enjoyed longer duration and favourable temperature for growth and development as compared to other sowing dates and produced maximum TDM. The results are in accordance with Ahmad et al. (2005) who stated that sowing dates had significantly different on dry matter production. The highest TDM increased from tillering to grain filing stage at November 25 sowing which might be due to the contribution of optimum sowing date in dry matter production. Similar trend was also observed in different growth stages of wheat by Alam, (2013). The increase of total dry matter was slow at the early stages of plant growth but increased rapidly with the advancement of plant age in all the sowing dates. The cause of rapid increase of TDM at later stages was possibly due to emergence of considerable number of new tillers plant ${ }^{-1}$ and fertile spike plant ${ }^{-1}$.

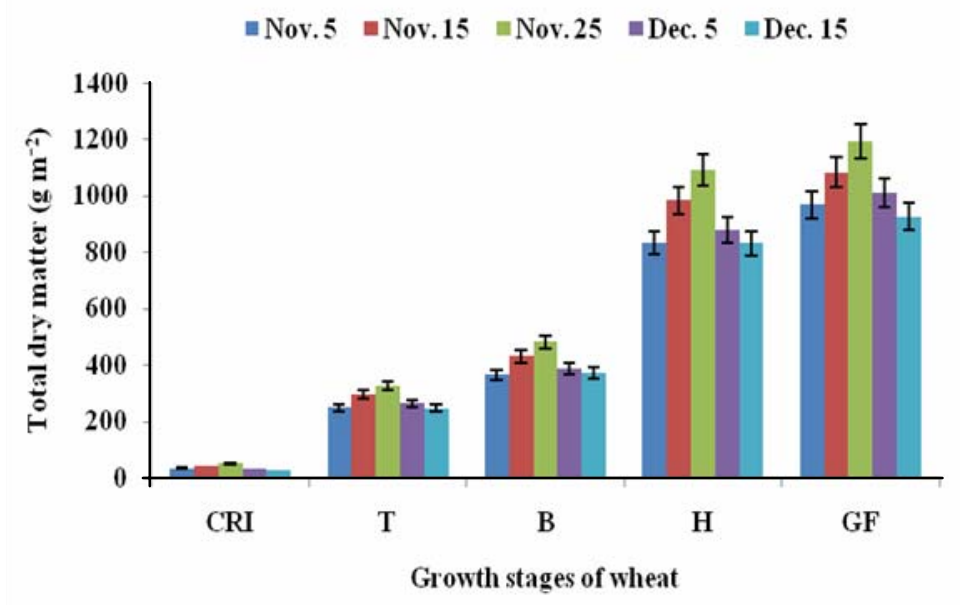

Fig. 1. Effect of sowing dates on total dry matter at different growth stages of wheat

$\mathrm{CRI}=$ Crown Root Initiation stage, $\mathrm{T}=$ Tillering stage, $\mathrm{B}=$ Booting stage, $\mathrm{H}=$ Heading stage and GF=Grain Filling stage

\section{Leaf area index (LAI)}

Green leaf area is the source of food production of green plants and significant variation was observed in leaf area index among the sowing dates. The maximum value for LAl was observed for November 25 sowing at booting stage where as late sowing (December15) showed lowest LAI (Fig. 2). This is due to optimum sowing time produced the highest LAl across the different sowing dates. This might be due to favourable synthesis of growth favouring constituents in plant system due to optimum sowing date which led to the increased number of leaves per unit area resulting in enlargement in leaf area. There was a general trend of declining LAl as the age of the plant advanced. This was because it was the transition period from vegetative to reproductive phase. These results are in agreement with Alam, (2013) who reported that LAI was higher at booting stage and then declined up to grain filing stage. 


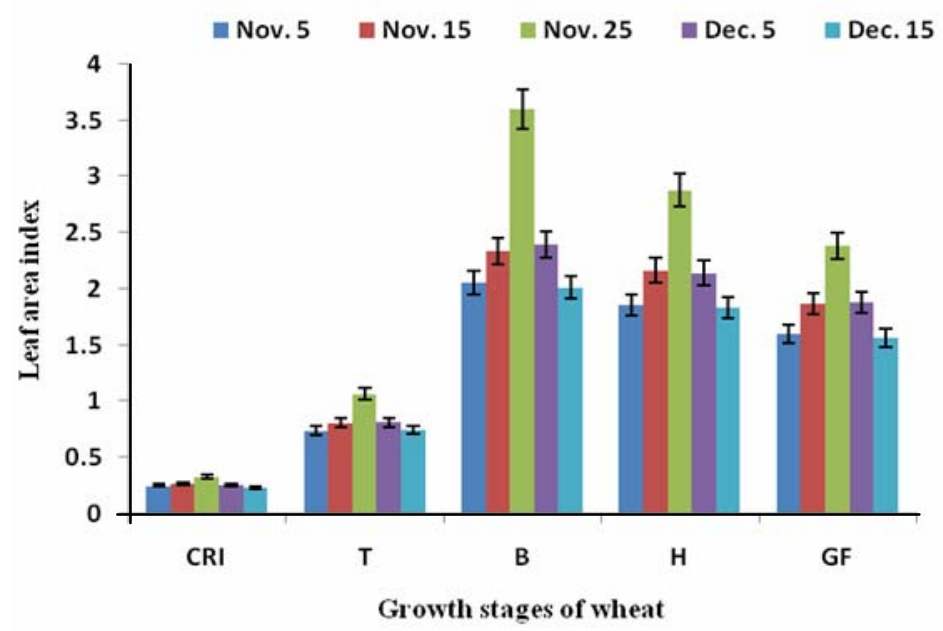

Fig. 2. Effect of sowing dates on leaf area index at different growth stages of wheat

$\mathrm{CRI}=$ Crown Root Initiation stage, $\mathrm{T}=$ Tillering stage, $\mathrm{B}=$ Booting stage, $\mathrm{H}=$ Heading stage and $\mathrm{GF}=\mathrm{Grain}$ Filling stage

\section{Crop growth rate (CGR)}

Optimum sowing date (November 25) produced the highest CGR values in all the growth stages (Fig. 3). Crop growth rate increased slowly at early stages of growth and reached the peak at booting to heading stage (44.98 $\mathrm{g} \mathrm{m}^{-2} \mathrm{day}^{-1}$ ) thereafter, it declined. This was due to the maximum production of dry matter at early stages of plant growth. These results are in accordance with Alam, (2013) who stated that crop growth rate was higher at booting and tillering stages. Crop growth rate represents the net result of photosynthesis, respiration and canopy area interception.

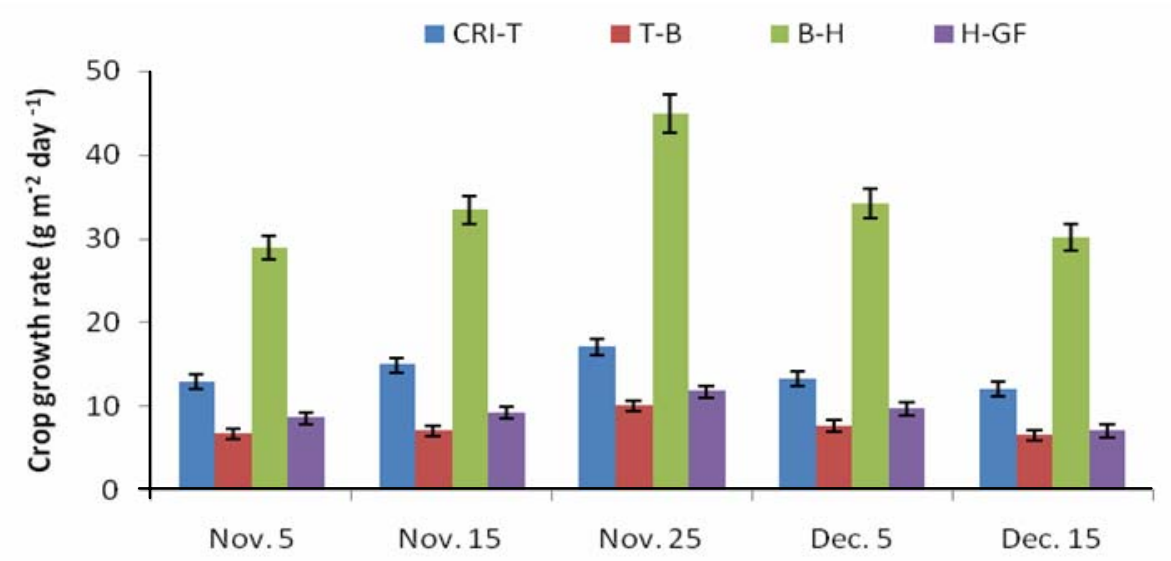

Fig. 3. Effect of sowing dates on crop growth rate at different growth stages of wheat

$\mathrm{CRI}=$ Crown Root Initiation stage, $\mathrm{T}=$ Tillering stage, $\mathrm{B}=$ Booting stage, $\mathrm{H}=$ Heading stage and $\mathrm{GF}=\mathrm{Grain}$ Filling stage

\section{Plant height at maturity (cm)}

Height of the crop is mainly controlled by the genetic make-up of a genotype and it can also be affected by the environmental factors (Shahzad et al., 2007). The data showed that plant height differed significantly by different sowing dates (Fig. 4). The maximum plant height $(97.93 \mathrm{~cm}$ ) was measured in 
November 25 which was statistically at par with other sowing dates except December 15 . November 25 sowing date produced taller plants $(97.93 \mathrm{~cm}$ ) because of the longer vegetative growth period, better environmental conditions especially the temperature and solar radiation (Qasim et al., 2008). The shortest and similar plants of 83.33 and $82.93 \mathrm{~cm}$ were observed on November 5 and December 15 due to shorter growing period. These results are partially supported by Baloch et al., (2012) who stated that increasing trend in plant height with the advancement of sowing dates upto November and thereafter decreasing in plant height.

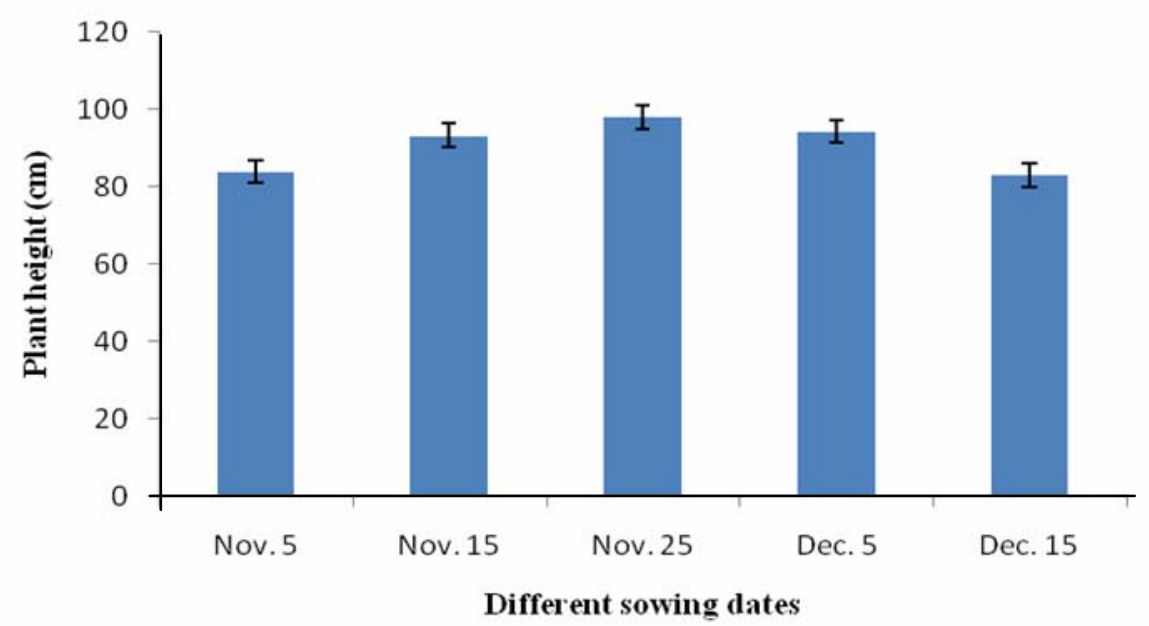

Fig. 4. Effect of different sowing dates on Plant height of wheat

\section{Yield contributing characters}

Number of effective tillers plant ${ }^{-1}$ : Tillering mainly depends upon the green photosynthetic area which is responsible for carbohydrate formation, grain filling and final grain yield. It has the great agronomic importance as this may compensate the difference in number of plants, partially or totally after crop establishment. It is evident from the data that sowing dates had significant effect on the number of effective tillers plant ${ }^{-1}$ (Table 1). However, sowing wheat on November 25 gave the maximum (3.49) number of effective tillers plant ${ }^{-1}$ followed by November 15. November 5 and December 15 were statistically at par in producing effective tillers plant ${ }^{-1}$ which showed the lowest (2.44) value for number of tillers.

Number of spikes $\mathrm{m}^{-2}$ : The economic yield of most of the cereals is determined by the number of spikes $\mathrm{m}^{-2}$. It has the great agronomic importance as this may compensate the difference in number of plants, partially or totally after crop establishment. It is evident from the data that sowing dates had significant effect on the number of spikes per unit area. However, sowing wheat on 25 November gave the maximum number of spikes $\left(311 \mathrm{~m}^{-2}\right)$ as compared to November 5 and December 15 which showed the lowest (233) value for number of spikes $\mathrm{m}^{-2}$ (Table 1 ).

Spike length $(\mathbf{c m})$ : The length of spike plays a vital role in wheat towards the grains spike ${ }^{-1}$ and yield (Shahzad et al., 2007). Sowing dates had significant effect on spike length (Table 1). Sowing wheat on November 25 produced the maximum $(9.67 \mathrm{~cm})$ and statistically at par to November 15 and December 5 sowing. Further delay in sowing resulted in shorter spike length. These findings are supported by Baloch et al., (2010) who reported that optimum sowing dates resulted in better spike development due to longer growing period. 
Number of grains spike ${ }^{-1}$ : Number of grains spike ${ }^{-1}$ is an important yield contributing parameter and has a direct effect on the grain yield of wheat. Data regarding number of grains spike ${ }^{-1}$ revealed that sowing $^{-1}$ dates did not affect significantly the number of grains spike ${ }^{-1}$ (Table 1). Seeds sown on November 25 produced more number of grains (42.20) and less number (33.10) of grains spike ${ }^{-1}$ produced on December 15 sowing due to shorter growing period less production of photosynthates and rise in temperature at the time of grain filling stage causing spikelet sterility. Similar observations are in line with those of Tahir et al., (2009).

Thousand grains weight: Thousand-grain weight is a genetic character and least influenced by the environment. There were non-significant variations among various sowing dates (Table 1 ). However, the crop sown on November 25 produced heavier seeds $(52.10 \mathrm{~g}$ ) followed by the crop sown on November 15. There was a gradual decrease in grain weight with each successive sowing after November 25 and the minimum grain weight $(42.20 \mathrm{~g})$ on December 15. Akhtar et al., (2006) reported that delayed sowing shortens the duration of each development phase which ultimately reduces gain filling period resulting in lower grain weight. On the other hand, the earlier sown crop enjoyed a prolonged growth period and favourable pre-heading conditions which have had a carryover effect on grain weight via stem reserves or the setting of potential grain weight soon after anthesis (Ortiz-Monasterio et al., 1994).

Table 1. Effect of dates of sowing on the yield contributing characters of wheat grown at FSRD site, Hatgobindapur, Faridpur during rabi 2012-13 and 2013-14 (pooled)

\begin{tabular}{l|c|c|c|cc}
\hline \multicolumn{1}{c|}{ Dates of sowing } & $\begin{array}{c}\text { No. of effective } \\
\text { tillers plant }^{-1}\end{array}$ & $\begin{array}{c}\text { No. of spikes } \\
\mathrm{m}^{-2}\end{array}$ & $\begin{array}{c}\text { Length of } \\
\text { spike }(\mathrm{cm})\end{array}$ & $\begin{array}{c}\text { No. of grains spike- } \\
1\end{array}$ & 1000-grain wt (g) \\
\hline November 05 & $2.48 \mathrm{~d}$ & $237 \mathrm{~b}$ & $7.52 \mathrm{~b}$ & 33.73 & 42.93 \\
November 15 & $2.98 \mathrm{~b}$ & $295 \mathrm{a}$ & $7.87 \mathrm{ab}$ & 38.83 & 48.87 \\
November 25 & $3.49 \mathrm{a}$ & $311 \mathrm{a}$ & $9.67 \mathrm{a}$ & 42.20 & 52.10 \\
December 05 & $2.71 \mathrm{c}$ & $290 \mathrm{a}$ & $8.52 \mathrm{ab}$ & 39.27 & 48.33 \\
December 15 & $2.44 \mathrm{~d}$ & $233 \mathrm{~b}$ & $7.02 \mathrm{c}$ & 33.10 & 42.20 \\
\hline CV (\%) & 6.57 & 7.22 & 6.85 & 6.42 & 5.21 \\
\hline
\end{tabular}

In a column, figures having common letter(s) do not differ significantly at $5 \%$ level by DMRT

Yield

Grain yield: Grain yield of wheat crop is the result of combined effect of various yield contributing components. It is evident from the data that sowing date affected significantly the grain yield (Table 2). Higher grain yield $\left(4.36 \mathrm{t} \mathrm{ha}^{-1}\right)$ was obtained from November 25 sowing which was statistically at par with November 15 and December 5 sowing. The highest yield was obtained due to cumulative effect of increased spike $\mathrm{m}^{-2}$, number of grains spike ${ }^{-1}$ and 1000-grain weight. The last sowing date December 15 produced the lowest $\left(3.27 \mathrm{t} \mathrm{ha}^{-1}\right)$ grain yield mainly due to less number of tillers $\mathrm{m}^{-2}$, less number of grains spike $^{-1}$ and lower 1000-grains weight. These results are in accordance with Sharma et al., (2006) who stated that wheat yield in late sowing by the end of December reduce the grain yield by $30-40 \%$ compared with normal sowing.

Straw yield: The straw yield is reflected by growth parameters like total number of tillers, leaf area and plant height. The data indicated that sowing dates significantly affected the straw yield. (Table 2). Significantly higher straw yield $\left(4.94 \mathrm{t} \mathrm{ha}^{-1}\right)$ was produced when the crop was sown on November 25 might be due to more number of tillers $\mathrm{m}^{-2}$ and more plant height. Straw yield decreased when plant got unfavourable environment at vegetative stage; as a result crop became thinned and produced less tillers which in turn decreased the straw yield. These results are in accordance with Donaldson et al., (2001).

Biological yield: Biological yield of wheat crop is the combined effect of various yield contributing components viz. higher germination $\mathrm{m}^{-2}$, more number of tillers $\mathrm{m}^{-2}$, more plant height, higher number of grains spike ${ }^{-1}$ and 1000-grain weight. It is evident from the data that sowing date exaggerated significantly the biological yield (Table 2.) Maximum biological yield $\left(9.30 \mathrm{t} \mathrm{ha}^{-1}\right)$ was recorded when the crop sown on November 25 which was statistically at par with November 15 and December 5. Minimum biological yield $\left(7.18 \mathrm{t} \mathrm{ha}^{-1}\right)$ was produced by November 5 which was statistically identical with December 15 . These findings are supported by Akram (2011). 
Harvest index $\mathbf{( H I ) : ~ T h e ~ a b i l i t y ~ o f ~ a ~ c r o p ~ t o ~ c o n v e r t ~ t o t a l ~ d r y ~ m a t t e r ~ i n t o ~ g r a i n ~ o r ~ e c o n o m i c ~ y i e l d ~ i s ~}$ indicated by its harvest index value. It is an important trait for selecting high yielding genotypes under normal and late planting condition. Higher harvest index indicative of efficient utilization of photosynthates and also associated with high yield under the stress condition (Blum et al., 1994). It was found that dates of sowing were significantly influenced the harvest index. Wheat sown on November 25 produced the highest harvest index (46.88\%) while minimum harvest index (45.35\%) was recorded late sown on December 15 (Table 2). Harvest index decreased markedly due to late planting. The decrease harvest index indicated that grain yield was reduced more than total biomass under late sowing conditions.

Table 2. Effect of sowing dates on grain, straw, biological yield and harvest index of wheat grown at FSRD site, Hatgobindapur, Faridpur during rabi 2012-13 and 2013-14 (pooled)

\begin{tabular}{l|c|c|c|c}
\hline \multicolumn{1}{c|}{ Dates of sowing } & $\begin{array}{c}\text { Grain yield } \\
\left(\mathrm{t} \mathrm{ha}^{-1}\right)\end{array}$ & $\begin{array}{c}\text { Straw yield } \\
\left(\mathrm{t} \mathrm{ha}^{-1}\right)\end{array}$ & $\begin{array}{c}\text { Biological yield } \\
\left(\mathrm{t} \mathrm{ha}^{-1}\right)\end{array}$ & $\begin{array}{c}\text { Harvest Index } \\
(\%)\end{array}$ \\
\hline November 05 & $3.29 \mathrm{~b}$ & $3.89 \mathrm{~b}$ & $7.18 \mathrm{~b}$ & 45.82 \\
November 15 & $3.78 \mathrm{a}$ & $4.42 \mathrm{ab}$ & $8.20 \mathrm{ab}$ & 46.05 \\
November 25 & $4.36 \mathrm{a}$ & $4.94 \mathrm{a}$ & $9.30 \mathrm{a}$ & 46.88 \\
December 05 & $3.90 \mathrm{a}$ & $4.60 \mathrm{ab}$ & $8.50 \mathrm{ab}$ & 45.88 \\
December 15 & $3.27 \mathrm{~b}$ & $3.94 \mathrm{~b}$ & $7.21 \mathrm{~b}$ & 45.35 \\
\hline CV (\%) & 6.87 & 6.82 & 5.68 & - \\
\hline
\end{tabular}

In a column, figures having common letter(s) do not differ significantly at $5 \%$ level by DMRT

\section{Conclusion}

From the result it may be assumed that growth yield components and yield of wheat were affected by the dates of sowing. In the present study, it visualized that wheat sown on November 15 to December 5 were significantly better compared to early (November 5) and too late condition (December 15) in respect to growth and yield of wheat may be confirmed with subsequent repeated trials under charland ecosystem of Bangladesh.

\section{References}

Ahmad, N., Shaha, N.H., Habibullah, M. and Khan, F.U. 2005. Effects of different seed rates, sowing dates and weed control on grain yield of wheat. Pakistan J. Weed Sci. Res., 11(3/4): 109-113.

Ahmed, M.M., Alam, N.K., Moniruzzaman, Abedin, Z. and Jasimuddin, G. 1987. Crop production in saline and charland existing situation and potentials. pp.1-27. In Advances in Agronomic Research in Bangladesh. Vol. 2.

Akhtar, M., Cheema, M.S., Jamil, M. and Ali, L. 2006. Effect of time of sowing on some important characters of wheat (Triticum aestivum) genotypes. J. Agril. Res., 44 (4): 255-259.

Akram, M. 2011. Growth and yield components of wheat under water stress of different growth stages. Bangladesh J. Agril. Res., 36 (3): 455-468.

Alam, M.S. 2013. Growth and yield potentials of wheat as affected by management practices. African J. Agril. Res., 8(47): 60686072.

Badruddin, M., Saunders, D. A., Siddique, A. B., Hossain M. A., Ahmed, M. U., Rahman, M. M. and Parveen, S. 1994. Determing yield constraints for wheat production in Bangladesh. 265-271pp.

Baloch, M.S., Nadim, M.A., Zubair, M., Awan, I.U., Khan, E.A. and Ali, S. 2012. Evaluation of wheat under normal and late sowing conditions. Pakistan J. Botany., 44 (5): 1727-1732.

Baloch, M.S., Shah, I.T.H., Nadim, M.A., Khan, M.I. and Khakwani, A.A. 2010. Effect of seeding density and application time on growth and yield attributes of wheat. J. Animal \& Plant Sci., 20 (4): 239-242.

BBS (Bangladesh Bureau of Statistics). 2012. Year Book of Agricultural Statistics of Bangladesh. Planning Division, Ministry of Planning, Government of People's Republic of Bangladesh. Dhaka. Published in August, 2013.

Blum, A., Sinmena, B., Mayer, J., Golam, G. and Shpiler, L. 1994. Stem reserve mobilization supports wheat-grain filling under heat stress. Australian J. Plant Physol., 21: 771-781.

Coasta R., Pinheiro, N., Ameida, A.S., Gomes, C., Coutinho, J., Coco, J., Costa, A. and Nacas, B. 2013. Effect of sowing date and seeding ratio on bread wheat yield and test weight under Mediterranean conditions. Emirates J. Food and Agric., 25: 951961. 
DAE (Department of Agriculture Extension). 2010. Annual Review Report. Presentation in RARS, BARI, Barisal, 2010.

Donaldson, E., Schillinger, W.F. and Dofing, S.M. 2001. Straw production and grain yield relationship in winter wheat. Crop Sci., 41: 100-106.

Gardner, F.P., Pearce, R.B. and Mitchell, R.L. 1985. Physiology of crop plants. The IOWA state Univ. Press, IOWA 50010, $156-186$.

Gomez, K.A. and Gomez, A.A. 1984. Statistical procedures of Agricultural Research. $2^{\text {nd }}$ (ed.) John Wiley and sons, New York.

Hunt, R. 1978. Plant growth analysis. Edward Arnold, London, UK.

Kamruzzaman, M. M. 2013. Agronomic practices on yield of wheat varieties in low Ganges river floodplain soil of Bangladesh. Ph. D. Thesis. Department of Agronomy. American University, USA.

Ortiz-Monasterio, J.J.R., Dhillonb, S.S. and Hischer, R.A. 1994. Date of sowing effects on grain yield and yield components of irrigated spring wheat cultivars and relationships with radiation and temperature in Ludhiana, India. Field Crops Res., 37 : 169-184.

Qasim, M., Qamer, M., Fariduallah and Alam, M. 2008. Sowing dates effect on yield and yield components of different wheat varieties. J. Agril. Res., 46 (2): 135-140.

Shahzad, M.A., Din, W.U., Sahi, S.T., Khan, M.M., Ehsanullah and Ahmad, M. 2007. Effect of sowing dates and seed treatment on grain yield and quality of wheat. Pakistan J. Agril. Sci., 44 (4): 581-583.

Sharma, N.P., Sumesh, K.V., Vaibhav, D.L. and Ghildiyal, M.C. 2006. High temperature effect on grain yield in wheat cultivar: an evaluation of responses. J. Plant Physol., 11 (3): 239-245.

Singh, V.P.N. and Uttam, S.K. 1999. Influence of sowing dates on yield of wheat cultivars under saline sodic conditions in Central Utter Pradesh. Indian Agric., 38 (1): 64-68.

Tahir, M., Ali, A., Nadeem, M.A., Hussain, A. and Khalid, F. 2009. Effect of different sowing dates on growth and yield of wheat varieties in district Jhang, Pakistan. Pakistan J. Life and Soc. Sci., 7 (7): 66-69.

Wiegard, C.L. and Cellular, J.A. 1981. Duration of grain filling and kernel weight of wheat as affected by temperature. Crop Sci. 2:95-101. 